\title{
Ketahanan Pangan Rumah Tangga, Kejadian Sakit dan Sanitasi Lingkungan Berhubungan dengan Status Gizi Balita Usia 1-5 Tahun Di Surabaya
}

\section{Household Food Security, Incidence of Illness, and Environment Sanitation is Associated with Nutritional Status of 1-5 Years Old Children in Surabaya}

\author{
Hernita Riski ${ }^{* 1}$, Luki Mundiastutik², Annis Catur Adi ${ }^{3}$
}

\begin{abstract}
ABSTRAK
Latar Belakang: Ketahanan pangan merupakan salah satu aspek penting yang berperan dalam pencapaian Susteinable Development Goals (SDGs). Berdasarkan tujuan kedua SDGs, ketahanan pangan dapat dikatakan tercapai apabila masyarakat telah bebas dari kelaparan, akses pangan yang aman dan bergizi tercukupi untuk semua orang. Ketahanan pangan merupakan aspek yang penting karena mampu mempengaruhi status gizi masyarakat terutama balita. Menurut Riskesdas 2018, di Indonesia prevalensi status gizi kurang dan gizi buruk pada balita sebesar 13,85\% dan 3,9\%.

Tujuan: Menganalisis hubungan ketahanan pangan rumah tangga, kejadian sakit, dan sanitasi lingkungan dengan status gizi balita di Kelurahan Sidotopo Kecamatan Semampir Kota Surabaya.

Metode: Penelitian ini menggunakan desain cross sectional. Besar sampel sebanyak 64 rumah tangga. Pengambilan sampel dilakukan dengan cara multistage random sampling. Pengumpulan data dilakukan dengan menggunakan kuisioner USHFSSM untuk mengetahui status ketahanan pangan rumah tangga, kuisioner sanitasi lingkungan untuk mengetahui status sanitasi lingkungan rumah, dan kuisioner umum untuk mengetahui identitas responden, kejadian sakit dan status gizi responden. Penelitian dianalisis dengan uji korelasi spearman.

Hasil: Ketahanan pangan memiliki hubungan yang signifikan dengan status gizi $B B / U(p<0,001)$ dengan koefisien korelasi sebesar 0,463 , kejadian sakit memiliki hubugan signifikan dengan status gizi berdasarkan indeks $B B / U(p=0,001)$ dengan koefisien korelasi sebesar $-0,390$, dan sanitasi lingkungan memiliki hubungan signifikan dengan status gizi berdasarkan indeks $B B / U(p=0,039)$ dengan koefisien korelasi sebesar 0,259.

Kesimpulan: Terdapat hubungan ketahanan pangan rumah tangga, kejadian sakit, dan sanitasi lingkungan dengan status gizi balita.
\end{abstract}

Kata Kunci: Ketahanan pangan rumah tangga, kejadian sakit, sanitasi lingkungan, status gizi balita

\section{ABSTRACT}

Background: Food security is an important aspect that plays a role in achieving the Sustainable Development Goals (SDGs). Based on the second purpose of SDGs, food security can be achieved if the community has been free from hunger, access to safe and nutritious food is sufficient for everyone. Food security is an important aspect because it can influence the nutritional status of the community, especially children. According to Riskesdas 2018, in Indonesia the prevalence of malnutrition and malnutrition in children are $13.85 \%$ and $3.9 \%$.

Objectives: To analyze the relationship of household food security, incidence of illness, and environmental sanitation with nutritional status of children in Sidotopo, Semampir Surabaya.

Method: This research used cross sectional design. The sample size was 64 household. Sampling was done by multistage random sampling. Data was collected through interview using US-HFSSM, recall 2x24hours, environmental sanitation, and general questionnaire. The result was analyzed using spearman test.

Result: Food security had a significant relationship between nutritional status WAZ ( $p<0.001)$, the incidence of illness had a significant relationship with nutritional status WAZ $(p=0.001)$, and environmental sanitation had a significant relationship with nutritional status with WAZ ( $p=0.039$ ).

Conclusion: The conclusion that there were relationship of household food security, incidence of illness, and environmental sanitation with nutritional status of children.

Keywords: Household food security, incidence of illness, environmental sanitation, nutritional status of children 
*Koresponden:

riski.hernita@gmail.com

1,3 Departemen Gizi Kesehatan, Fakultas Kesehatan Masyarakat-Universitas Airlangga

Kampus C Mulyorejo, 60115 Surabaya, Jawa Timur, Indonesia

${ }^{2}$ Akademi Gizi Surabaya, Jl. Bendul Merisi No.126, 60239, Bendul Merisi, Kec. Wonocolo, Kota SBY, Jawa Timur, Indonesia

\section{PENDAHULUAN}

Susteinable Development Goals (SDGs) merupakan tujuan yang dapat dicapai dengan memperhatikan salah satu aspek penting seperti ketahanan pangan. Ketahanan pangan merupakan salah satu tujuan untuk mencapai SDGs yang termasuk pada tujuan kedua yaitu mengakhiri kelaparan, menggapai ketahanan pangan, dan menambah gizi serta meningkatkan pertanian yang berkelanjutan. Berdasarkan tujuan kedua SDGs, ketahanan pangan dapat dikatakan tercapai apabila masyarakat telah bebas dari kelaparan, akses pangan yang aman dan bergizi tercukupi untuk semua orang ${ }^{1}$.

Ketahanan pangan suatu wilayah dapat digambarkan salah satunya dengan ketersediaan pangan di wilayah tersebut ${ }^{2}$. Menurut Badan Ketahanan Pangan, ketersediaan pangan di Indonesia mempunyai nilai yang fluktuatif, pada tahun 2013 hingga tahun $2017^{3}$. Tahun 2013 sebesar $3.770 \mathrm{kkal} / \mathrm{kap} / \mathrm{hari}$ menurun menjadi $3.731 \mathrm{kkal} / \mathrm{kap} / \mathrm{hari}$ (2014) dan menurun kembali menjadi $3.515 \mathrm{kkal} / \mathrm{kap} / \mathrm{hari}$ (2015), kemudian meningkat menjadi $3.964 \mathrm{kkal} / \mathrm{kap} / \mathrm{hari}$ (2016) dan 4.006 kkal/kap/hari (2017). Ketersediaan pangan yang telah melebihi standar masih belum sesuai dengan tingkat konsumsi masyarakat Indonesia. Konsumsi pangan masyarakat Indonesia memiliki nilai yang fluktuatif sejak tahun 2013 sampai tahun 2017. Pada tahun 2013 sebesar $1.930 \mathrm{kkal} / \mathrm{kap} /$ hari meningkat menjadi 1.949 kkal/kap/hari (2014), $2.099 \mathrm{kkal} / \mathrm{kap} / \mathrm{hari}$ (2015), 2.147 $\mathrm{kkal} /$ kap/hari (2016), tetapi kemudian menjadi 2.128 $\mathrm{kkal} /$ kap/hari (2017). Selain dapat menyebabkan masalah rawan pangan, konsumsi pangan yang tidak memenuhi standar juga dapat mempengaruhi status gizi khususnya balita yang merupakan kelompok rawan (vulnerable group $)^{4}$.

Pada tahun 2009 sebanyak 346 daerah yang tersebar di 32 provinsi di Indonesia mengalami rawan pangan, sedangkan data pada tahun 2015 jumlah daerah rawan pangan sebanyak 398 daerah yang tersebar di 34 provinsi di Indonesia ${ }^{5}$. Ketahanan pangan yang kurang dapat mengakibatkan penurunan derajat kesehatan dan menyebabkan status gizi menjadi kurang ${ }^{6}$. Oleh karena itu ketahanan pangan memiliki hubungan yang erat dengan kesehatan dan gizi. Walaupun tidak menderita penyakit tetapi mengalami ketahanan pangan yang kurang pada kurun waktu tertentu maka mampu menyebabkan kekurangan gizi.

Faktor yang mempengaruhi status gizi dipengaruhi oleh tiga faktor yang luas yaitu makanan, kesehatan, dan pola asuh7. Sanitasi buruk, penyakit, malnutrisi, dan stunting (akibat malnutrisi kronis) merupakan hal yang saling berkaitan ${ }^{8}$. Penyakit infeksi yang dialami balita mampu menyebabkan penurunan status gizi balita. Apabila balita mengalami asupan pangan yang kurang terutama energi dan protein dalam jangka waktu tertentu maka dapat menyebabkan penurunan berat badan sehingga mampu mengakibatkan penurunan daya tahan tubuh dan balita menjadi mudah terserang penyakit ${ }^{9}$.

Di Indonesia, prevalensi gizi kurang menunjukkan nilai yang fluktuatif. Pada tahun 2007 sebesar 13\%, kemudian naik sebesar $0,9 \%$ menjadi $13,9 \%$, dan pada tahun 2018 menurun menjadi 13,85\%. Sedangkan prevalensi gizi buruk pada tahun 2007 sebesar 5,4\%, kemudian meningkat sebesar $0,3 \%$ menjadi $5,7 \%$, dan menurun sebesar $1,8 \%$ menjadi $3,9 \%{ }^{10}$.

Berdasarkan Penilaian Status Gizi (PSG) dan Profil Kesehatan Kota Surabaya tahun 2014 Puskesmas Sidotopo memiliki jumlah balita dengan status gizi kurang dengan indikator BB/U pada tahun 2014 yaitu $21,6 \%{ }^{11}$. Kemudian, pada tahun 2016 prevalensi gizi kurang di Puskesmas Sidotopo menurun menjadi 18,75\% ${ }^{12}$. Tetapi pada tahun 2017 prevalensi gizi kurang di Puskesmas Sidotopo menjadi 20,7\%, dengan prevalensi di Kelurahan Sidotopo $22,1 \%^{13}$.

$\mathrm{Hal}$ di atas menjelaskan bahwa Kelurahan Sidotopo masih memiliki jumlah prevalensi gizi kurang yang cukup tinggi. Berdasarkan uraian tersebut, perlu adanya penelitian untuk mengetahui hubungan antara ketahanan pangan rumah tangga, kejadian sakit, dan sanitasi lingkungan dengan status gizi balita di Kelurahan Sidotopo.

\section{METODE}

Penelitian ini adalah penelitian observasional analitik dengan desain cross sectional. Penelitian dilakukan di Kelurahan Sidotopo Kecamatan Semampir Kota Surabaya pada tahun 2019. Populasi pada penelitian ini adalah rumah tangga yang memiliki balita usia 1-5 tahun di Kelurahan Sidotopo. Pengambilan sampel dilakukan dengan multistage random sampling dengan pengambilan sampel dilakukan secara bertingkat. Besar sampel dihitung dengan menggunakan rumus Lemeshow dan mendapatkan hasil sebanyak 64 sampel. Responden dalam penelitian ini adalah ibu balita. Kriterian inklusi pada penelitian ini adalah rumah tangga yang memiliki balita berusia 1-5 tahun yang tinggal di wilayah Kelurahan Sidotopo, sehat, bersedia menjadi responden, dan tidak mengalami kendala keterbatasan verbal atau tuna wicara.

Ketahanan pangan rumah tangga diukur menggunakan kuisioner United States Household Food Security Survey Module (US-HFSSM) ${ }^{14}$. Kuisioner USHFSSM terdapat 18 pertanyaan yang menggambarkan kondisi ketahanan pangan dalam 12 bulan terakhir dengan total skor 18 . Jawaban dengan respon negatif diberi skor 0 dan jika jawaban mendapat respon positif maka mendapat skor 1 . Skor dijumlah dan dikategorikan 
menjadi 4 kategori ketahanan pangan, yaitu tahan pangan (jika skor 0-2), rawan pangan tanpa kelaparan (jika skor 3-7), rawan pangan dengan derajat kelaparan sedang (jika skor 8-12) dan rawan pangan dengan derajat kelaparan berat (jika skor 13-18). Pengukuran penyakit diare dilakukan dengan menanyakan riwayat penyakit diare kepada ibu balita selama dua minggu terakhir sebelum dilakukan wawancara. Sanitasi lingkungan diukur dengan menggunakan kuisioner penilaian rumah sehat menurut Depkes RI $2007^{15}$.

Status gizi anak balita dinilai dengan melakukan pengukuran antropometri WHO (2005) kepada balita menggunakan Berat Badan menurut umur (BB/U) yang dilakukan oleh peneliti. Alat ukur berat badan yang digunakan unttuk mengukur berat badan balita adalah timbangan digital dengan merk Omron $\mathrm{HN}-286$. BB/U dikategorikan menjadi gizi lebih $>2 S D$, gizi baik -2 SD s/d 2 SD, gizi kurang -3 SD s/d -2 SD, dan gizi buruk <-3 SD.

\section{HASIL DAN PEMBAHASAN}

Hasil penelitian menunjukkan bahwa sebanyak $39,1 \%$ rumah tangga kategori tahan pangan, dan $60,9 \%$ rumah tangga kategori rawan pangan. Dapat diketahui bahwa lebih dari separuh mengalami rawan pangan, dan diantaranya terdapat rumah tangga yang tergolong rawan pangan tingkat berat.

Berdasarkan Tabel 1 terdapat 22 keluarga $(34,4 \%)$ yang memiliki balita gizi normal berdasarkan indeks $\mathrm{BB} / \mathrm{U}$ dan memiliki status ketahanan pangan tahan pangan. Hasil uji statisik menunjukkan terdapat hubungan signifikan antara status ketahanan pangan rumah tangga dengan status gizi balita berdasarkan indeks $\mathrm{BB} / \mathrm{U}$. Kerawanan pangan dapat berpengaruh terhadap konsumsi makanan dan memperparah keadaan gizi karena dapat mengurangi baik secara kualitas maupun kuantitas makanan. Selain itu kerawanan pangan juga dapat menyebabkan stres, depresi, pola pengasuhan dan pemberian makan pada bayi sehingga dapat mempengaruhi status gizi ${ }^{16}$.
Penilaian rumah sehat memiliki tiga kelompok dalam rumah yang dinilai, yaitu komponen rumah, sarana sanitasi, dan perilaku penghuni. Tiap kelompok memiliki bobot penilaian yang berbeda, yaitu untuk komponen rumah memiliki bobot $31 \%$, sarana sanitasi memiliki bobot $25 \%$, dan perilaku penghuni memiliki bobot $44 \%$. Rumah dengan sanitasi yang buruk atau tidak memenuhi syarat memiliki skor penilaian $<80 \%$, sedangkan rumah dengan sanitasi yang baik atau memenuhi syarat yaitu apabila skor yang dihasilkan adalah $80-100 \%$.

Hubungan ketahanan pangan rumah tangga, kejadian sakit, dan sanitasi lingkungan dengan status gizi balita dianalisis menggunakan uji korelasi Spearman. Penelitian ini telah lolos uji etik dengan nomor 1290-KEPK dari komisi etik Fakultas Keperawatan Universitas Airlangga dan Badan Kesatuan Bangsa dan Politik (Bakesbangpol) Kota Surabaya dengan nomor 070/2115/436.8.5/2019 tanggal 20 Februari 2019.

Apabila keluarga tidak mampu memenuhi kebutuhan pangan anggota keluarganya secara fisiologis dan kesehatan maka dapat terjadi kekurangan dan kerawanan pangan ${ }^{17}$. Balita mampu mendapatkan zat gizi yang sesuai kebutuhan apabila pangan balita dapat tercukupi dari segi akses dan kualitas, sehinga dapat berpengaruh terhadap status gizi. Keluarga rawan pangan memiliki risiko 5.707 kali memiliki anak balita dengan status gizi kurang ${ }^{18}$. Gizi buruk atau gizi kurang pada balita dapat terjadi jika asupan makanan tidak cukup dalam kurun waktu tertentu.

Berdasarkan tabel 2, diketahui bahwa balita yang mengalami diare selama 2 minggu terakhir mayoritas memiliki status gizi kurang berdasaran indeks $\mathrm{BB} / \mathrm{U}$ yaitu sejumlah 8 balita (12,5\%). Sedangkan balita yang tidak mengalami diare paling banyak memiliki status gizi normal yaitu sejumlah 37 balita (57,8\%). Berdasarkan hasil uji korelasi Spearman menunjukkan bahwa terdapat hubungan signifikan antara kejadian sakit balita dengan status gizi balita berdasarkan indeks BB/U dengan koefisien korelasi -0,390 (negatif).

Tabel 1. Distribusi Tingkat Ketahanan Pangan Rumah Tangga dengan Status Gizi Balita BB/U

\begin{tabular}{|c|c|c|c|c|c|c|c|c|c|c|c|}
\hline \multirow{3}{*}{$\begin{array}{c}\text { Status Ketahanan } \\
\text { Pangan Rumah Tangga }\end{array}$} & \multicolumn{8}{|c|}{ Status Gizzi BB/U } & \multicolumn{2}{|c|}{ Total } & \multirow{3}{*}{$\begin{array}{c}P \\
\text { value }\end{array}$} \\
\hline & \multicolumn{2}{|c|}{ Gizi Buruk } & \multicolumn{2}{|c|}{ Gizi Kurang } & \multicolumn{2}{|c|}{ Gizi Normal } & \multicolumn{2}{|c|}{ Gizi Lebih } & \multirow{2}{*}{$\mathrm{n}$} & \multirow{2}{*}{$\%$} & \\
\hline & $n$ & $\%$ & $n$ & $\%$ & $\mathbf{N}$ & $\%$ & $\mathbf{N}$ & $\%$ & & & \\
\hline Tahan pangan & 0 & 0 & 1 & 4 & 22 & 88 & 2 & 8 & 25 & 100 & \\
\hline $\begin{array}{l}\text { Rawan pangan tingkat } \\
\text { ringan }\end{array}$ & 1 & 4,3 & 10 & 43,5 & 12 & 52,2 & 0 & 0 & 23 & 100 & \\
\hline $\begin{array}{l}\text { Rawan pangan tingkat } \\
\text { sedang }\end{array}$ & 0 & 0 & 5 & 41,7 & 7 & 58,3 & 0 & 0 & 12 & 100 & $<0,001$ \\
\hline $\begin{array}{l}\text { Rawan pangan tingkat } \\
\text { berat }\end{array}$ & 0 & 0 & 3 & 75 & 1 & 25 & 0 & 0 & 4 & 100 & \\
\hline
\end{tabular}

Tabel 2. Distribusi Tingkat Kejadian Sakit dengan Status Gizi Balita BB/ $U$

\begin{tabular}{|c|c|c|c|c|c|c|c|c|c|c|c|}
\hline \multirow{3}{*}{ Kejadian Sakit } & \multicolumn{8}{|c|}{ Status Gizi BB/U } & \multicolumn{2}{|c|}{ Total } & \multirow{3}{*}{$\begin{array}{c}P \\
\text { value }\end{array}$} \\
\hline & \multicolumn{2}{|c|}{ Gizi Buruk } & \multicolumn{2}{|c|}{ Gizi Kurang } & \multicolumn{2}{|c|}{ Gizi Normal } & \multicolumn{2}{|c|}{ Gizi Lebih } & \multirow{2}{*}{ n } & \multirow{2}{*}{$\%$} & \\
\hline & $\mathbf{n}$ & $\%$ & $\mathbf{n}$ & $\%$ & $\mathbf{n}$ & $\%$ & $\mathbf{N}$ & $\%$ & & & \\
\hline Tidak & 0 & 0 & 11 & 22 & 37 & 74 & 2 & 4 & 50 & 100 & 0,001 \\
\hline Ya & 1 & 7,1 & 8 & 57,2 & 5 & 35,7 & 0 & 0 & 14 & 100 & \\
\hline
\end{tabular}


Tabel 3. Distribusi Tingkat Sanitasi Lingkungan dengan Status Gizi Balita BB/U

\begin{tabular}{|c|c|c|c|c|c|c|c|c|c|c|c|}
\hline \multirow{3}{*}{ Sanitasi Lingkungan } & \multicolumn{8}{|c|}{ Status Gizi BB/U } & \multicolumn{2}{|c|}{ Total } & \multirow{3}{*}{$\begin{array}{c}\mathbf{P} \\
\text { value }\end{array}$} \\
\hline & \multicolumn{2}{|c|}{ Gizi Buruk } & \multicolumn{2}{|c|}{ Gizi Kurang } & \multicolumn{2}{|c|}{ Gizi Normal } & \multicolumn{2}{|c|}{ Gizi Lebih } & \multirow{2}{*}{$n$} & \multirow{2}{*}{$\%$} & \\
\hline & $\mathbf{n}$ & $\%$ & $\mathrm{n}$ & $\%$ & $\mathbf{n}$ & $\%$ & $\mathbf{n}$ & $\%$ & & & \\
\hline Tidak memenuhi syarat & 1 & 2,32 & 16 & 37,2 & 25 & 58,1 & 1 & 2,33 & 43 & 100 & \\
\hline Memenuhi syarat & 0 & 0 & 3 & 14,2 & 17 & 81 & 1 & 4,8 & 21 & 100 & 0,039 \\
\hline
\end{tabular}

Hal tersebut sejalan dengan penelitian Hidayat (2011) yang menyebutkan bahwa terdapat hubungan antara anak balita yang pernah mengalami diare dengan status gizi balita berdasarkan $\mathrm{BB} / \mathrm{U}^{19}$. Balita yang sering mengalami diare memiliki peluang menderita kurang gizi, pendek, dan kurus, satu kali lebih besar daripada anak balita dengan status gizi normal atau status gizi baik. Balita yang mengalami diare dapat mengalami gangguan metabolisme dan menyebabkan ketidakseimbangan hormon sehingga dapat menurunkan imunitas. Menurut Safitri (2017) menyebutkan bahwa terdapat hubungan signifikan antara hygiene dan sanitasi lingkungan dengan diare pada balita usia 13-48 bulan ${ }^{20}$. Balita yang mengalami diare dapat disebabkan karena memiliki sanitasi lingkungan rumah yang kurang baik. Diare merupakan penyait yang berbasis lingkungan yang pada dasarnya pada penularannya sebagian besar berasal dari air dan pangan yang memiliki sanitasi yang buruk yang dapat disebabkan oleh mikroorganisme ${ }^{21}$.

Berdasarkan hasil penelitian menunjukkan terdapat sebagian besar tempat tinggal di Kelurahan Sidotopo memiliki sanitasi yang belum memenuhi syarat, baik dari aspek komponen rumah, sarana sanitasi, dan perilaku penghuni. Hasil uji statistik menggunakan uji korelasi Spearman menunjukkan hasil sebesar 0,039 yang artinya terdapat hubungan signifikan antara sanitasi lingkungan dengan status gizi balita berdasarkan indeks BB/U.

Hasil tersebut sejalan dengan penelitian Hidayat (2011) yang menunjukkan bahwa terdapat hubungan bermakna antara status gizi berdasarkan BB/U dengan sanitasi lingkungan ${ }^{19}$. Peluang balita yang tumbuh di lingkungan tidak sehat satu kali lebih besar mengalami status gizi buruk, daripada pada anak balita status gizi normal atau anak balita status gizi baik. Depkes RI menyebutkan bahwa aspek penilaian komponen rumah dibutuhkan untuk menilai kenyamanan keluarga dalam segi jenis bangunan dan pertukaran udara yang keluar maupun masuk, sehingga anggota keluarga mendapatkan oksigen yang cukup di dalam rumah ${ }^{15}$. Untuk melihat tingkat kebersihan dalam rumah agar tidak menjadi tempat persebaran kuman dan bakteri yang merugikan bagi tubuh dibutuhkan aspek sarana sanitasi dan perilaku penghuni.

Kekurangan pada penelitian ini adalah pada pengukuran penyakit diare bersifat subjektif dengan menanyakan riwayat penyakit diare kepada ibu balita selama dua minggu terakhir sebelum dilakukan wawancara. Kelebihan penelitian ini adalah dapat bermanfaat bagi peneliti lain dengan menyediakan data yang dapat digunakan untuk bahan perbandingan dan penelitian sejenis di waktu yang akan datang, sehingga dapat dijadikan studi literatur pada penelitian serupa.

\section{KESIMPULAN}

Terdapat hubungan signifikan antara status ketahanan pangan rumah tangga, kejadian sakit, dan sanitasi lingkungan dengan status gizi balita. Agar status gizi balita dapat meningkat maka perlu adanya peningkatan ketahanan pangan rumah tangga dan peningkatan sanitasi lingkungan untuk menekan kejadian sakit terutama diare pada balita.

\section{ACKNOWLEDGEMENT}

Peneliti mengucapkan terima kasih kepada Badan Kesatuan Bangsa dan Politik Kota Surabaya, Dinas Kesehatan Kota Surabaya, dan Puskesmas Sidotopo yang telah mengizinkan penelitian dilakukan, ibu kader dan responden yang telah bersedia membantu penelitian, serta dosen pembimbing atas bimbingannya yang telah diberikan.

\section{REFERENS}

1. Badan Pusat Satistik. Potret Awal Pembangunan Pasca MDGs, Sustainable Development Goals (SDG ). (Badan Pusat Statistik, 2015).

2. Arisman Dr.M. Gizi dalam Daur Kehidupan. (Penerbit Buku EGC, 2008).

3. Kementrian Pertanian. Statistik Ketahanan Pangan. (Badan Ketahanan Pangan Kementrian Pertanian, 2017).

4. Purwantini, T. B. Pendekatan Rawan Pangan Dan Gizi: Besaran, Karakteristik, Dan Penyebabnya. Forum Penelit. Agro Ekonomi. 32, 1-17 (2014).

5. Pusdatin (Pusat Data dan Informasi). Buku Data dan Informasi Perkembangan Daerah Tertentu Daerah Rawan Pangan. (Badan Penelitian dan Pengembangan, Pendidikan dan Pelatihan, dan Informasi, 2015).

6. Arlius, A., Sudargo, T. \& Subejo, S. Hubungan Ketahanan Pangan Keluarga Dengan Status Gizi Balita (Studi Di Desa Palasari Dan Puskesmas Kecamatan Legok, Kabupaten Tangerang). J. Ketahanan Nasional. 23, 359-375 (2017).

7. UNICEF. UNICEF 's Approach to Scaling Up Nutrition for Mothers and Their Children. (United Nation Children's Fund, 2015).

8. World Bank. Indonesia Economic Quarterly. (The World Bank, 2016).

9. Jayani, I. Hubungan Antara Penyakit Infeksi dengan Status Gizi pada Balita. Java Heal Joernal 2, 1-8 (2014).

10. Riskesdas. Hasil Utama Laporan Riskesdas 2018. (Badan Penelitian dan Pengembangan Kesehatan Departemen Kesehatan Republik Indonesia, 2018). 
11. Rahma, A. C. \& Nadhiroh, S. R. Perbedaan Sosial Ekonomi dan Pengetahuan Gizi Ibu Balita Gizi Kurang dan Gizi Normal. Media Gizi Indonesia. 11, 55-60 (2016).

12. Puskesmas Sidotopo. Laporan Bulanan Puskesmas Sidotopo Tahun 2016. (UPT Puskesmas Sidotopo, 2016).

13. Puskesmas Sidotopo. Laporan Bulanan Puskesmas Sidotopo Tahun 2017. (UPT PUskesmas Sidotopo, 2017).

14. Bickel, G., Nord, M., Price, C., Hamilton, W. \& Cooc, J. Guide to Measuring Household Food Security. (U.S. Department of Agriculture, Food and Nutrition Service, 2000).

15. Depkes RI. Pedoman Teknis Penilaian Rumah Sehat. (Direkrotrat Jenderal Pengendalian Penyakit dan Penyehatan Lingkungan, 2007).

16. Chaparro, C. Household Food Insecurity and Nutritional Status of Women of Reproductive Age and Children Under 5 Years of Age in Five Departments of the Western Highlands of Guatemala: An Analysis of Data from the
National Maternal-Infant Health Survey 2008 09 of Gu. (FANTA FHI 360, 2012).

17. Rahmadi, Sudargo, T. \& Wijanarka, A. Perilaku Sadar Gizi dan Ketahanan Pangan Keluarga serta Hubungannya dengan Status Gizi Balita di Kabupaten Tanah. J. Gizi dan Dietetik Indonesia. 1, 31-38 (2013).

18. Osei, A. et al. Household Food Insecurity and Nutritional Status of Children Aged 6 to 23 Months in Kailali District of Nepal. 31, 483-494 (2010).

19. Hidayat, T. S. \& Fuada, N. Hubungan Sanitasi Lingkungan, Morbiditas dan Status Gizi Balita di Indonesia. PGM 34, 104-113 (2011).

20. Safitri, C. A. \& Nindya, T. S. Hubungan Ketahanan Pangan dan Penyakit Diare dengan Stunting pada Balita 13-48 Bulan di Kelurahan Manyar Sabrangan , Surabaya. Amerta Nutr 1, 52-61 (2017).

21. Achmadi, U. Dasar-Dasar Penyakit Berbasis Lingkungan. (Rajawali Pers, 2011). 